\title{
OPTIMASI TOPOLOGI DAN UKURAN PENAMPANG STRUKTUR RANGKA BATANG BAJA DENGAN METODE METAHEURISTIK
}

\author{
Ricky Agusta ${ }^{1}$, Hieronimus Enrico Suryo ${ }^{1}$, Doddy Prayogo ${ }^{1}$, Wong Foek Tjong ${ }^{1}$, dan \\ Ghanshyam Tejani ${ }^{2}$ \\ ${ }^{1}$ Departemen Teknik Sipil, Fakultas Teknik Sipil dan Perencanaan, Universitas Kristen \\ Petra, Jalan Siwalankerto 121-131, Surabaya 60236, Indonesia \\ 2 Department of Mechanical Engineering, School of Technology, GSFC University, \\ Vadodara, Gujarat, India \\ 1rickyagusta.h@gmail.com, ${ }^{1}$ m21415011@john.petra.ac.id, prayogo@petra.ac.id1, \\ wftiong@petra.ac.id ${ }^{1}$, p.shyam23@gmail.com²
}

\begin{abstract}
ABSTRAK: Optimasi topologi dari struktur rangka batang baja memberikan hasil yang lebih optimal dibandingkan optimasi ukuran penampang karena batang dan nodes yang tidak berguna pada struktur dapat dihilangkan. Fungsi objektif dari algoritma metaheuristik adalah untuk meminimalkan massa struktur rangka batang baja terhadap constraints statis dan dinamis berdasarkan studi kasus dan spesifikasi bangunan baja struktural Indonesia, SNI 1729:2015. Empat algoritma yang digunakan pada studi ini adalah: Particle Swarm Optimization, Differential Evolution, Teaching-Learning-Based Optimization, dan Symbiotic Organisms Search. Keempat algoritma tersebut diuji pada studi kasus 24-bar truss. Performa dari algoritma diukur dari lima kriteria massa, yaitu: massa terbaik, terburuk, rata-rata, standar deviasi, dan median dari struktur rangka batang baja. Hasil penelitian menunjukkan SOS menunjukkan performa terbaik pada studi kasus 24-bar truss.
\end{abstract}

Kata kunci: optimasi, topologi, ukuran penampang, metaheuristik, SNI 1729:2015

ABSTRACT: Topology optimization of steel truss structure shows better results compared to sizing optimization because unnecessary bars and nodes that exist in a structure can be removed. The metaheuristic algorithms objective function is to minimize the mass of the steel truss structure subjected to static and dynamic constraints based on the the case study and Indonesian code specification for structural steel buildings, SNI 1729:2015. Four algorithms are used in this study, namely: Particle Swarm Optimization, Differential Evolution, TeachingLearning-Based Optimization, and Symbiotic Organisms Search. The algorithms are tested on a 24-bar truss case study. Performance of algorithms is measured based on five mass critera. The five mass criteria are best, worst, average, standard deviation, and median mass of steel truss structure. The results show that SOS has the best performance in the 24-bar truss case study.

Keywords: optimization, topology, cross section, metaheuristic, SNI 1729:2015

\section{PENDAHULUAN}

Optimasi rangka batang merupakan salah satu tipe optimasi struktural yang paling populer (Kaveh \& Talatahari, 2009). Optimasi rangka batang sendiri dapat dikelompokkan menjadi 
tiga kategori: optimasi ukuran penampang, bentuk, dan topologi (Deb \& Gulati, 2001). Penelitian ini hanya mempertimbangkan optimasi ukuran penampang dan topologi saja, di mana konektivitas dan ukuran penampang menjadi variabel optimasi. Material rangka batang juga merupakan salah satu faktor untuk dapat menghasilkan struktur yang optimal. Baja merupakan material yang sangat baik untuk pengaplikasian pada struktur rangka batang. Hal ini didasarkan karena baja tergolong ringan, kuat dan mudah untuk diaplikasikan. Dalam mendesain struktur baja, massa total struktur baja digunakan sebagai patokan fungsi objektif. Dimana objektif akhir dari penelitian ini adalah meminimalkan massa total struktur rangka batang baja melalui kombinasi topologi rangka batang dan ukuran penampang batang.

Penelitian mengenai struktur rangka batang pada penelitian-penelitian sebelumnya cenderung hanya menggunakan constraints statis saja sebagai parameter desain struktur. Pada kenyataannya, struktur rangka batang tersebut juga mengalami beban dinamis pada masa layannya, sehingga frekuensi natural dari struktur juga merupakan parameter penting dalam mendesain struktur (Savsani, Tejani, \& Patel, 2016). Dalam mendesain bangunan struktur baja tersebut diperlukan spesifikasi desain. SNI 1729:2015 telah digunakan baik oleh praktisi maupun peneliti dalam mendesain struktur baja, maka SNI 1729:2015 dapat dikategorikan sebagai spesifikasi desain yang terpercaya untuk mendesain struktur baja.

Desainer pada umumnya menggunakan intuisi dan pengalaman sebelumnya dalam mendesain topologi rangka batang. Metode tersebut belum tentu dapat menghasilkan topologi yang optimal. Metaheuristik merupakan salah satu metode untuk mengoptimasi berbagai macam kasus optimasi, karena metaheuristik mudah diaplikasikan, terjamin, dan derivativefree (Tejani, Savsani, Bureerat, \& Patel, 2017). Algoritma metaheuristik umumnya terinspirasi dari berbagai fenomena alam. Solusi-solusi dihasilkan melalui proses pengacakan agar algoritma bergerak dari optimum lokal menuju ke optimum global menjadikan metaheuristik sebagai metode yang efisien dalam menghasilkan solusi melalui metode trial and error dalam waktu yang cukup singkat (Yang, 2011). Penelitian ini bertujuan untuk membandingkan kinerja dari beberapa macam algoritma metaheuristik, yaitu Particle Swarm Optimization (PSO), Differential Evolution (DE), Teaching Learning Based Optimization (TLBO), dan Symbiotic Organisms Search (SOS) dalam kasus optimasi topologi dan ukuran penampang struktur rangka batang baja.

\section{LANDASAN TEORI}

Kata heuristik pada metaheuristik berasal dari Bahasa Yunani, heuriskein, yang berarti "untuk mencari", sedangkan kata meta berarti "prosedur yang lebih tinggi" (Bianchi, Dorigo, Maria Gambardella, \& J. Gutjahr, 2009). Maka, metaheuristik dapat didefinisikan sebagai metode dengan heuristik dengan tingkat prosedur yang lebih tinggi. Tiap algoritma metaheuristik memiliki strategi dan konsep dalam melakukan pencarian hasil yang optimal.

\subsection{Particle Swarm Optimization (PSO)}

Ditemukan oleh Kennedy dan Eberhart (1995), PSO merupakan algoritma yang sangat sederhana yang dapat dengan mudah diprogram pada komputer. PSO menirukan fenomena kawanan burung yang menggunakan posisi lokal masing-masing burung tersebut untuk menentukan lokasi (solusi) berikutnya. Mula-mula, inisialisasi partikel secara acak dilakukan pada ruang pencarian. Setiap partikel tersebut memiliki posisi dan kecepatan awal yang diperbarui melalui proses iterasi untuk menemukan hasil yang optimal. 


\subsection{Differential Evolution (DE)}

Berbasiskan evolutionary algorithm, DE merupakan algorithma algoritma metaheuristik yang dikembangkan oleh Storn dan Price (1997). Proses DE dibagi menjadi 3 tahap: mutasi, crossover, dan seleksi. Vektor mutasi terbentuk berdasarkan hasil mutasi terhadap tiga buah populasi yang dipilih secara acak pada tahap mutasi. Crossover terjadi antara populasi asli dan vektor mutasi untuk membentuk vektor trial. Suatu populasi tergantikan dengan vektor trial apabila vektor trial memiliki fitness value yang lebih baik dari fitness value populasi.

\subsection{Teaching-Learning-Based Optimization (TLBO)}

Menirukan proses belajar mengajar antara guru dan pelajar di ruang kelas, TLBO dikembangkan oleh Venkata Rao, Savsani, dan P. Vakharia (2011). Dalam algoritma ini, guru dianggap sebagai orang terpintar yang membagikan ilmunya kepada pelajar. TLBO dibagi menjadi 2 tahap, yaitu: fase guru dan fase pelajar. Dalam fase guru, guru mengangkat nilai dari pelajar menuju ke nilai dari guru tersebut. Pada fase murid, seorang murid secara acak berinteraksi atau berdiskusi dengan murid lainnya dengan harapan murid tersebut dapat belajar hal baru melalui interaksi dengan murid lain yang lebih pintar dari dia.

\subsection{Symbiotic Organisms Search (SOS)}

SOS merupakan salah satu algoritma metaheuristik modern yang ditemukan oleh Cheng dan Prayogo (2014). SOS mensimulasikan perilaku interaksi (simbiosis) antar organisme di dalam suatu ekosistem. SOS mengaplikasikan tiga jenis simbiosis yang paling umum, yaitu: simbiosis mutualisme, komensalisme, dan parasitisme. Dalam simbiosis mutualisme, dua organisme acak dipilih untuk berinteraksi secara mutualisme yang diharapkan dapat meningkatkan nilai kedua fitness value organisme tersebut. Hal serupa terjadi pada simbiosis komensalisme, hanya saja organisme kedua tidak mendapatkan keuntungan maupun kerugian dari hasil interaksi tersebut. Vektor parasit terbentuk dan menggantikan posisi dari suatu organisme apabila vektor parasit tersebut memiliki fitness value yang lebih baik dibandingkan fitness value dari organisme tersebut.

\subsection{Kapasitas Tarik dan Tekan berdasarkan SNI 1729:2015}

Profil Struktur Berongga (PSB) bulat dengan mutu BJ37 yang diambil dari (Gunawan, 1988) dengan total 49 ukuran digunakan sebagai desain variabel pada studi ini. Perhitungan kapasitas yang digunakan pada penelitian ini yaitu kapasitas tarik (BAB D) dan kapasitas tekan (BAB E) pada SNI 1729:2015.

\section{METODOLOGI PENELITIAN}

Secara umum, konsep pengerjaan optimasi topologi dan ukuran penampang rangka batang adalah dengan melalui proses iterasi menghilangkan atau mempertahankan batang pada ground structure. Ground structure merupakan bentuk dasar struktur yang berisi seluruh kombinasi dari segala kemungkinan konektivitas antar nodes di dalam studi kasus. Penjelasan dari proses eliminasi di dalam ground structure tersebut dapat dilihat pada Gambar 1. 


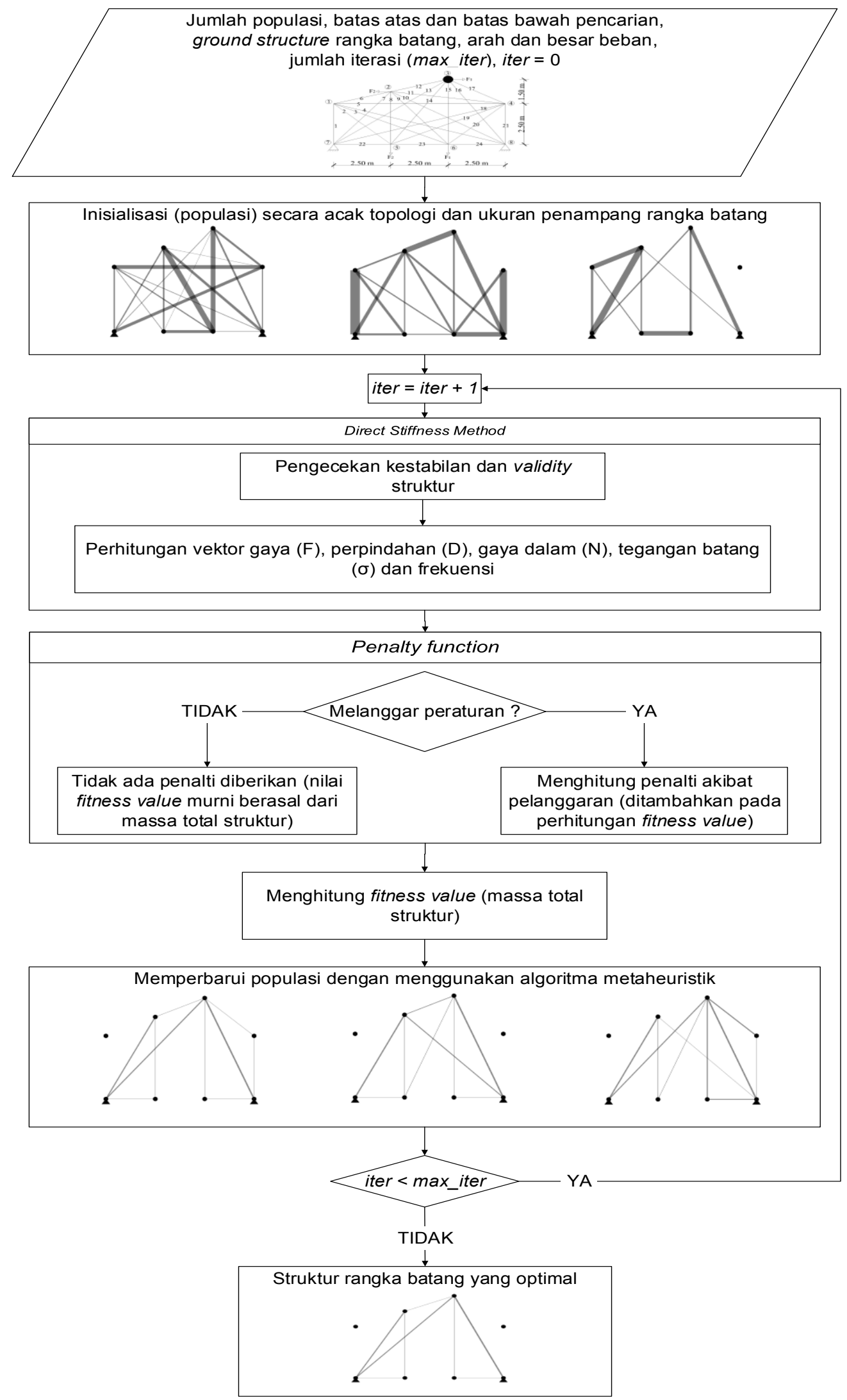

Gambar 1. Diagram Alir Optimasi Topologi dan Ukuran Penampang Struktur Rangka Batang 
Batas bawah dan atas dari variabel optimasi dalam kasus ini adalah 0 dan $D_{\max }$, di mana $D_{\max }$ adalah jumlah profil yang tersedia pada tabel profil (Gunawan, 1988), yaitu sebanyak 49 profil. Karena variabel optimasi bersifat diskrit, maka hasil optimasi dari algoritma harus dibulatkan terlebih dahulu. Apabila hasil pembulatan variabel optimasi $(D)$ tersebut adalah 0 , maka batang ke-i pada struktur tersebut dihilangkan dari struktur. Apabila hasil pembulatan variabel optimasi $(D)$ berkisar antara 1 hingga $D_{\max }$, maka batang ke-i menggunakan profil ke- $D$ dari urutan tabel profil. Untuk dapat membandingkan performa dari keempat algoritma tersebut, digunakan satu buah studi kasus, 24-bar truss, yang pertama kali diusulkan oleh Xu, Jiang, Tong, dan Wu (2003) pada penelitiannya. Kasus 24-bar truss juga telah digunakan oleh beberapa peneliti lainnya, seperti Kaveh dan Zolghadr (2013) dan juga oleh Tejani et al. (2017) untuk meneliti performa dari berbagai algoritma metaheuristik. Pada studi kasus 24-bar truss yang diusulkan (Xu et al., 2003) terdapat enam buah constraints statis dan dinamis, yaitu: constraint tegangan batang, perpindahan nodes, Euler buckling batang, frekuensi natural struktur, stabilitas struktur, dan validitas struktur. Karena pada penelitian ini digunakn SNI 1729:2015 sebagai acuan untuk menentukan kapasitas tarik dan tekan, maka tegangan batang dan constraint Euler buckling pada kasus awal dihilangkan. Kemudian, ditambahkan constraints kekuatan tarik dan tekan dari SNI 1729:2015. Berbagai macam topologi rangka batang terbentuk pada proses optimasi, dimungkinkan topologi struktur yang tidak stabil terbentuk pada proses tersebut. Maka dari itu diperlukan constraint stabilitas struktur untuk memastikan bahwa struktur yang terbentuk bersifat stabil. Constraint validitas struktur berfungsi untuk memastikan bahwa semua nodes perletakan dan beban dapat disalurkan melalui rangka batang. Masing-masing algoritma dijalankan sebanyak 30 runs dengan maskimal 100000 function evaluations untuk mengetahui konsistensi hasil optimasi dari masing-masing algoritma.

\section{HASIL DAN DISKUSI}

Ground structure dari 24-bar truss, pada Gambar 2, terdiri dari kombinasi 24 batang yang terhubung dengan 8 nodes.

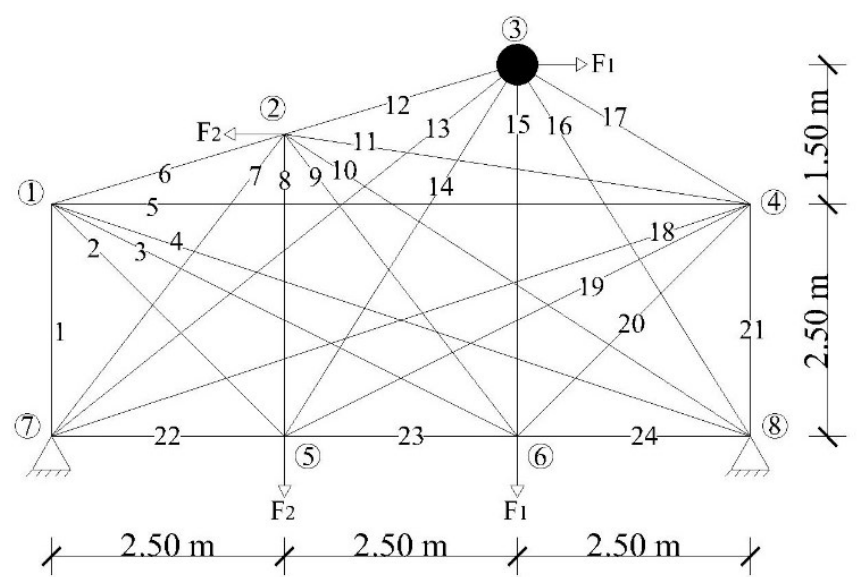

Gambar 2. Ground Structure dari Studi Kasus 24-Bar Truss

Tabel 1 menunjukkan pembebanan dan constraints dari kasus 24-bar truss. Terdapat dua kondisi pembebanan dalam kasus ini, dimana hasil akhir optimasi harus memenuhi kedua kondisi pembebanan tersebut. Pada node 3 terdapat massa terpusat yaitu sebesar $500 \mathrm{~kg}$. 
Perpindahan maksimum vertikal pada nodes 5 dan 6 adalh $0.01 \mathrm{~mm}$. Constraint dinamis yaitu frekuensi minimum pada mode ke-1 adalah $30 \mathrm{~Hz}$.

Tabel 1. Beban dan Constraints dari Studi Kasus 24-Bar Truss

\begin{tabular}{lll}
\hline \multicolumn{1}{c}{ Parameter } & \multicolumn{2}{c}{ Nilai } \\
\hline Kondisi pembebanan 1 $(\mathrm{N})$ & $F_{1}=5 \times 10^{4}$ & $F_{2}=0$ \\
Kondisi pembebanan 2 $(\mathrm{N})$ & $F_{1}=0$ & $F_{2}=5 \times 10^{4}$ \\
Massa terpusat di node 3 $(\mathrm{kg})$ & 500 & \\
Perpindahan maksimum $(\mathrm{mm})$ & 10 & \\
(nodes 5 dan 6 z-axis) & & \\
Frekuensi minimum $(\mathrm{Hz})$ & 30 \\
$\left(1{ }^{\text {st }}\right.$ mode $)$ & \\
\hline
\end{tabular}

Tabel 2 menunjukkan hasil optimasi pada kasus 24-bar truss dengan menggunakan keempat algoritma. SOS mampu memperoleh hasil massa teringan pada kasus ini yaitu sebesar $150.26 \mathrm{~kg}$. Dalam segi massa terburuk, rata-rata, standar deviasi, dan median SOS juga mampu mengungguli ketiga algoritma lainnya. Diurutan kedua untuk kelima massa kriteria tersebut adalah DE dengan masa terbaik 157.27. PSO dan TLBO berada diurutan ke-3 dan 4, dimana PSO mampu menungguli TLBO pada kriteria massa terbaik dan median. TLBO menungguli PSO pada ketiga kriteria lainnya, yaitu: massa terburuk, rata-rata, dan standar deviasi.

Gambar 3 menunjukkan grafik konvergensi dari run median dari masing-masing algoritma. Pada run median terlihat SOS tetap menungguli ketiga algoritma lainnya dalam kemampuan untuk menemukan massa teringan struktur. SOS mampu menghasilkan massa teringan tersebut dengan function evaluations yang sedikit yaitu pada function evaluation ke \pm 30000 .

Gambar 4 memaparkan evolusi dari ground structure mula-mula menjadi hasil optimasi akhir pada 100000 function evaluations untuk masing-masing algoritma. Dari gambar tersebut dapat disimpulkan bahwa topologi terbaik untuk seluruh algoritma tidak menggunakan nodes 1 dan 4 (lihat Gambar 2 untuk lebih jelasnya). Hal ini ditandai dengan seluruh batang ground structure yang menuju ke titik tersebut tereliminasi pada saat proses optimasi. Salah satu alasan dari hilangnya node tersebut adalah karena node tersebut tidak termasuk dalam node wajib (node beban dan perletakan) yang harus ada pada struktur. Nodes 7 dan 8 merupakan lokasi perletakan dan nodes 2, 3, 5, dan 6 merupakan lokasi beban. Sehingga hasil optimasi pada struktur tersebut hanya menggunakan node wajib saja. 
Tabel 2. Hasil dari Studi Kasus 24-Bar Truss

\begin{tabular}{llrrrr}
\hline Variabel & & \multicolumn{1}{c}{ PSO } & \multicolumn{1}{c}{ DE } & \multicolumn{1}{c}{ TLBO } & \multicolumn{1}{c}{ SOS } \\
\hline $\mathrm{A}_{1}-\mathrm{A}_{6}$ & $\mathrm{~mm}^{2}$ & 0.00 & 0.00 & 0.00 & 0.00 \\
$\mathrm{~A}_{7}$ & $\mathrm{~mm}^{2}$ & 863.60 & 863.60 & 1117.00 & 759.10 \\
$\mathrm{~A}_{8}$ & $\mathrm{~mm}^{2}$ & 291.90 & 229.10 & 291.90 & 229.10 \\
$\mathrm{~A}_{9}$ & $\mathrm{~mm}^{2}$ & 0.00 & 0.00 & 0.00 & 0.00 \\
$\mathrm{~A}_{10}$ & $\mathrm{~mm}^{2}$ & 158.30 & 576.00 & 123.80 & 123.80 \\
$\mathrm{~A}_{11}$ & $\mathrm{~mm}^{2}$ & 0.00 & 0.00 & 0.00 & 0.00 \\
$\mathrm{~A}_{12}$ & $\mathrm{~mm}^{2}$ & 0.00 & 456.40 & 0.00 & 0.00 \\
$\mathrm{~A}_{13}$ & $\mathrm{~mm}^{2}$ & 646.50 & 0.00 & 646.50 & 576.00 \\
$\mathrm{~A}_{14}$ & $\mathrm{~mm}^{2}$ & 0.00 & 179.90 & 0.00 & 123.80 \\
$\mathrm{~A}_{15}$ & $\mathrm{~mm}^{2}$ & 351.00 & 291.90 & 291.90 & 291.90 \\
$\mathrm{~A}_{16}$ & $\mathrm{~mm}^{2}$ & 989.20 & 989.20 & 989.20 & 989.20 \\
$\mathrm{~A}_{17}-\mathrm{A}_{21}$ & $\mathrm{~mm}^{2}$ & 0.00 & 0.00 & 0.00 & 0.00 \\
$\mathrm{~A}_{22}$ & $\mathrm{~mm}^{2}$ & 0.00 & 123.80 & 123.80 & 123.80 \\
$\mathrm{~A}_{23}$ & $\mathrm{~mm}^{2}$ & 123.80 & 0.00 & 0.00 & 0.00 \\
$\mathrm{~A}_{24}$ & $\mathrm{~mm}^{2}$ & 123.80 & 123.80 & 123.80 & 123.80 \\
$f_{1}$ & $\mathrm{~Hz}$ & 30.71 & 30.03 & 30.74 & 30.62 \\
$\delta_{5 \text { (ver.) }}$ & $\mathrm{mm}$ & 3.11 & 3.87 & 2.50 & 2.54 \\
$\delta_{6 \text { (ver.) }}$ & $\mathrm{mm}$ & 3.75 & 4.40 & 4.33 & 4.30 \\
Terbaik & $\mathrm{kg}$ & 157.66 & 157.27 & 162.35 & 150.26 \\
Terburuk & $\mathrm{kg}$ & 460.70 & 314.56 & 360.56 & 276.54 \\
Rata-rata & $\mathrm{kg}$ & 262.51 & 206.18 & 258.27 & 180.35 \\
Standar deviasi & $\mathrm{kg}$ & 81.54 & 36.23 & 50.98 & 33.64 \\
Median & $\mathrm{kg}$ & 234.25 & 199.29 & 260.99 & 163.13 \\
FE & & 100000 & 100000 & 100000 & 100000 \\
\hline & & & & & \\
\hline
\end{tabular}

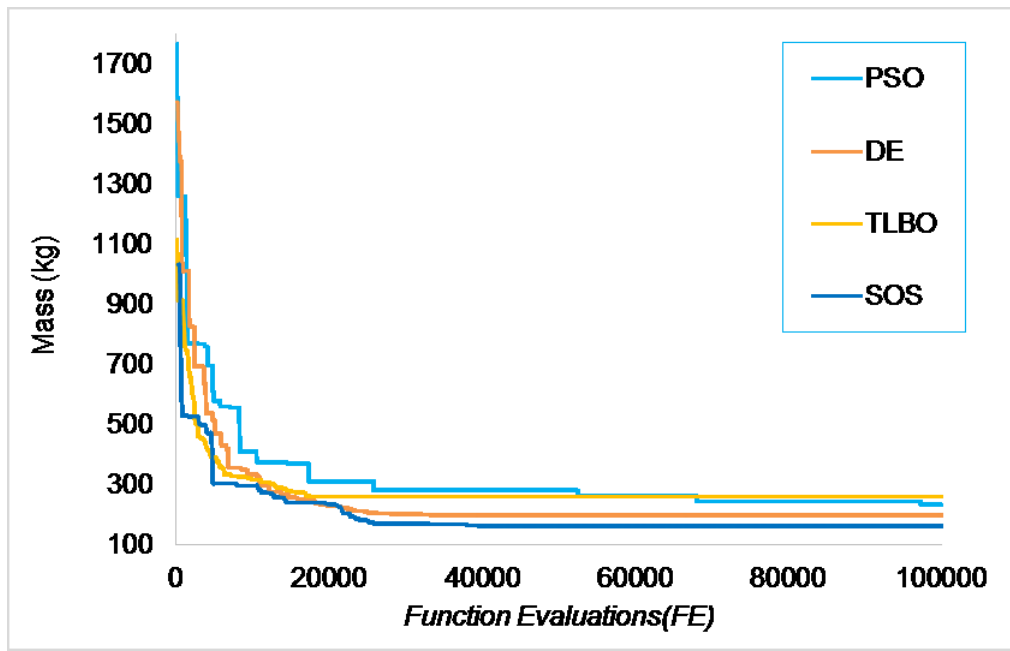

Gambar 3. Grafik Konvergensi Kasus 24-Bar Truss

Keempat grafik pada Gambar 5 digunakan untuk mengukur nilai efisiensi desain diukur dari SNI 1729:2015. Untuk pembebanan 1 dapat dilihat bahwa pada Gambar 5(a), hasil optimasi SOS di batang ke-15 mencapai nilai efisiensi 0.79. Sedangkan di pembebanan 2 pada Gambar 5(b) SOS juga mampu menghasilkan batang ke-8 dengan nilai efisiensi 0.87. Sedangkan untuk batang tekan di pembebanan 1 pada Gambar 4.4(c), DE mampu menghasilkan batang ke-10 dengan nilai efisieni 0.95. Pada Gambar 5(d), SOS mampu menghasilkan batang ke-7 dengan nilai efisiensi mencapai 0.97 . 


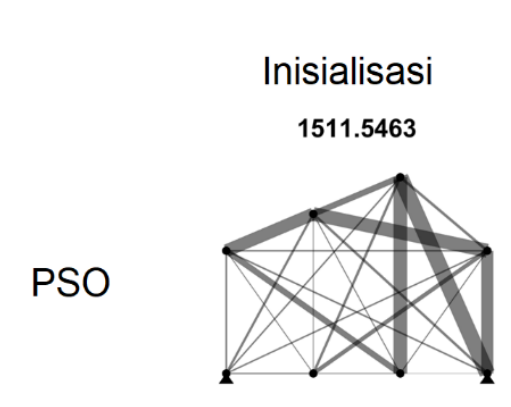

1607.5301

DE

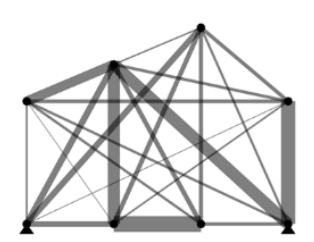

1553.4375

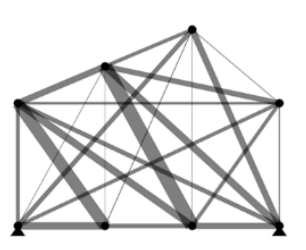

1519.22

SOS

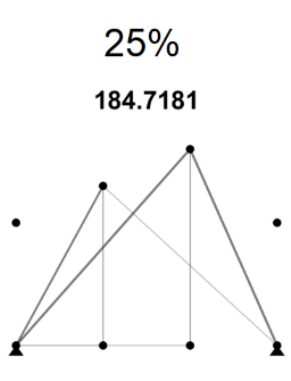

466.5916

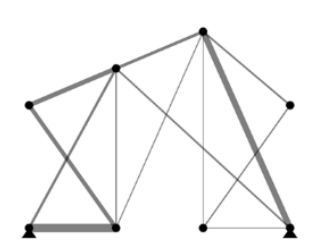

393.9988

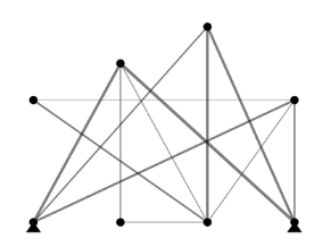

343.7942

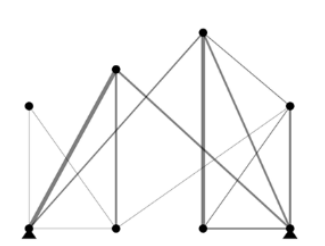

$50 \%$

182.3711

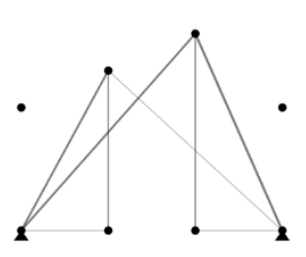

262.5816

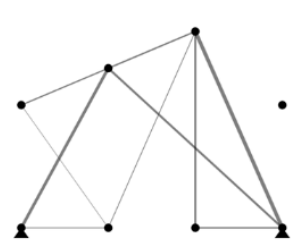

274.1023

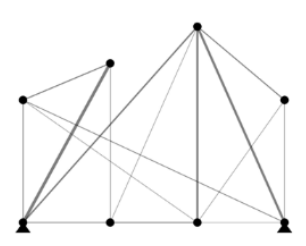

222.7939

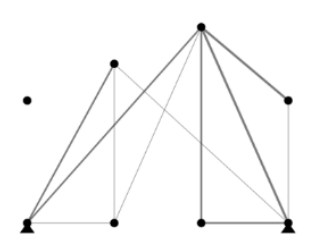

$75 \%$

177.0749

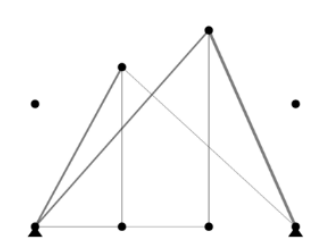

181.3708

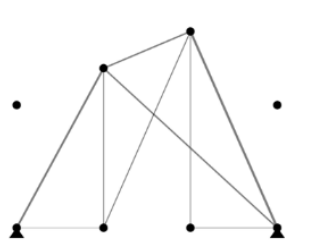

186.5594

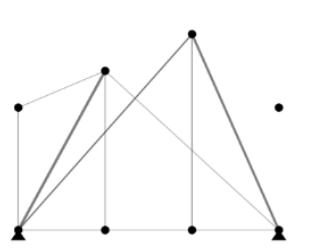

206.6861

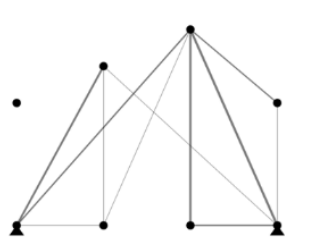

$100 \%$

157.6597

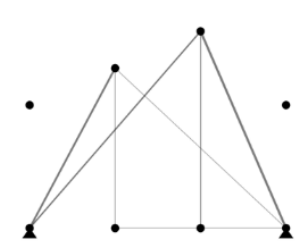

157.2721

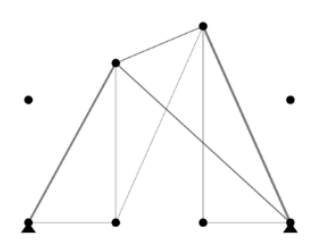

162.3452

Gambar 4. Proses Evolusi Topologi dan Penampang Kasus 24-Bar Truss

Function

Evaluations

94250 


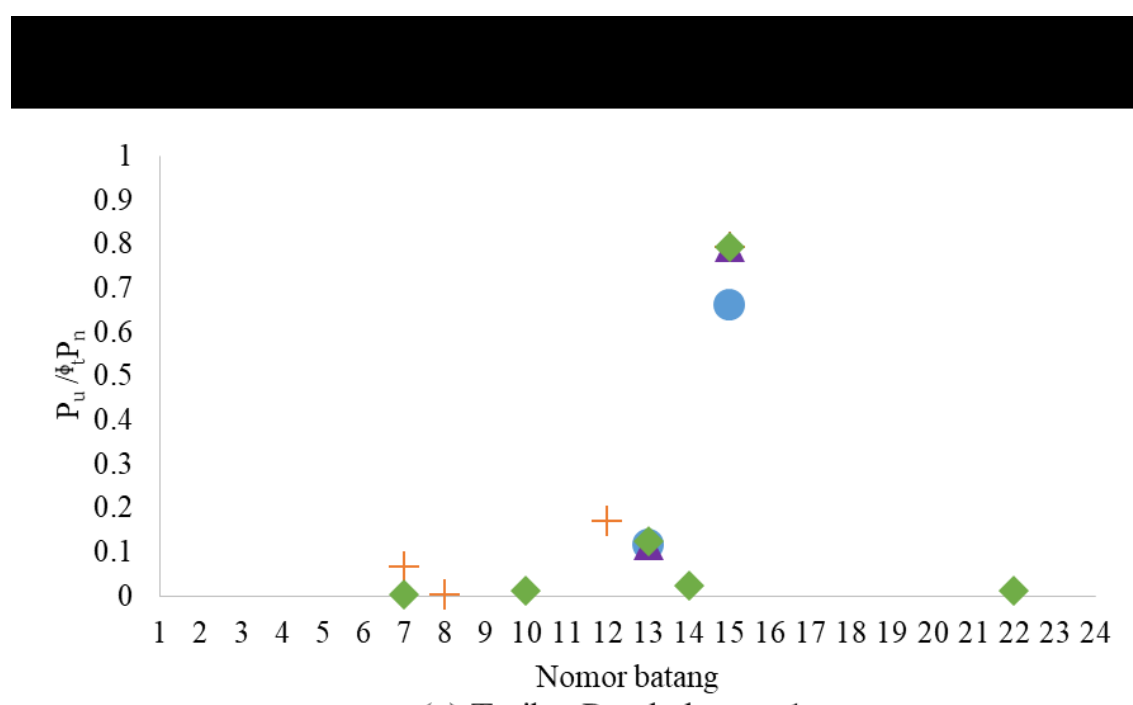

(a) Tarik - Pembebanan 1

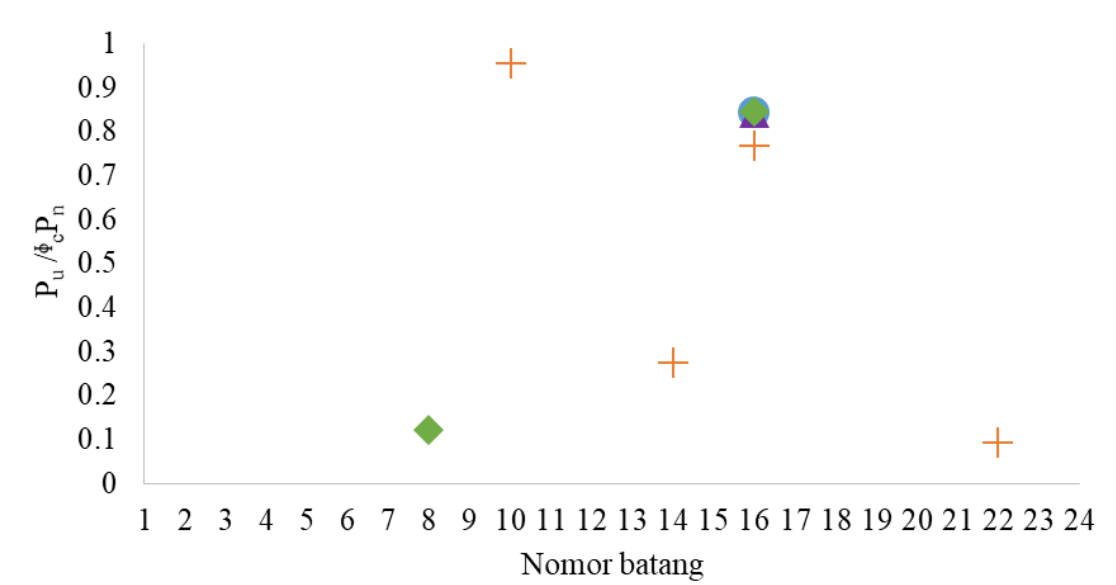

(c) Tekan - Pembebanan 1

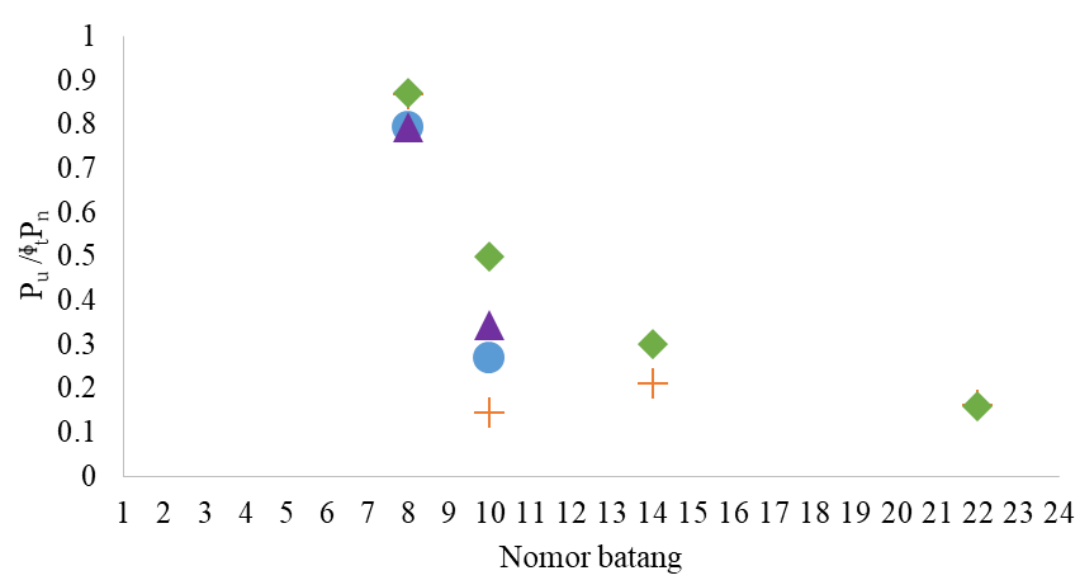

(b) Tarik - Pembebanan 2

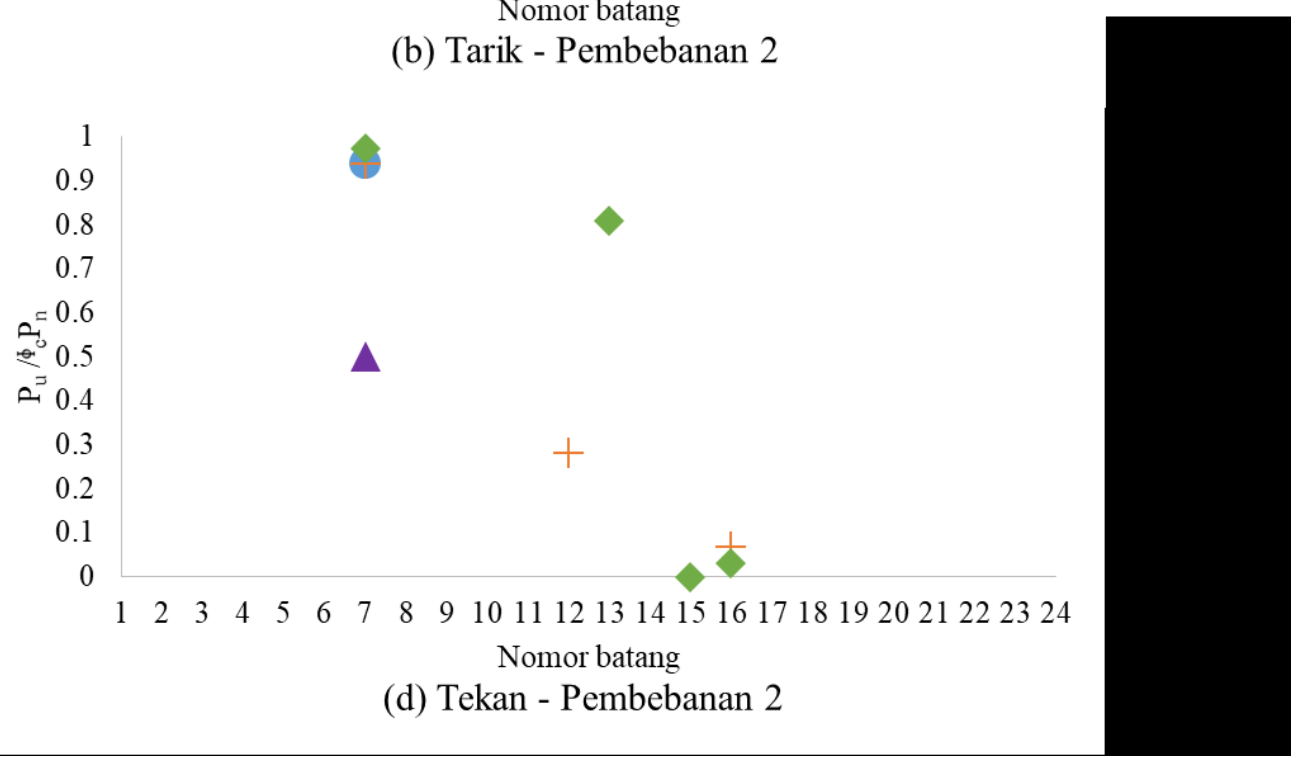

Gambar 5. Perbandingan Nilai Efisiensi Desain terhadap SNI 1729:2015 dari Tiap Batang pada Kasus 24-Bar Truss
- PSO

$+\mathrm{DE}$

$\triangle$ TLBO

$\rightarrow$ SOS 


\section{KESIMPULAN DAN SARAN}

Peneliti telah membandingkan performa dari empat algoritma metaheuristik, yaitu: PSO, DE, TLBO, dan SOS dalam kasus optimasi topologi dan ukuran penampang struktur rangka baja dengan menggunakan SNI 1729:2015 pada studi kasus 24-bar truss. Algoritma SOS menunjukkan performa yang lebih baik dibandingkan ketiga algoritma lainnya untuk kelima kriteria massa tersebut. Untuk penelitian selanjutnya, penelitian ini dapat dikembangkan untuk optimasi struktur rangka batang baja yang mempertimbangkan faktor bentuk (shape) dari struktur rangka batang tersebut.

\section{DAFTAR REFERENSI}

Bianchi, L., Dorigo, M., Maria Gambardella, L., \& J. Gutjahr, W. (2009). A Survey on Metaheuristics for Stochastic Combinatorial Optimization (Vol. 8).

Cheng, M.-Y., \& Prayogo, D. (2014). Symbiotic Organisms Search: A New Metaheuristic Optimization Algorithm. Computers \& Structures, 139, 98-112. doi: https://doi.org/10.1016/j.compstruc.2014.03.007

Deb, K., \& Gulati, S. (2001). Design of Truss-Structures for Minimum Weight Using Genetic Algorithms. Finite Elements in Analysis and Design, 37(5), 447-465. doi: https://doi.org/10.1016/S0168-874X(00)00057-3

Gunawan, R. (1988). Tabel Profil Konstruksi Baja (Vol. 7th): Kanisius.

Kaveh, A., \& Talatahari, S. (2009). Size Optimization of Space Trusses Using Big Bang-Big Crunch Algorithm. Computers \& Structures, 87(17), 1129-1140. doi: https://doi.org/10.1016/j.compstruc.2009.04.011

Kaveh, A., \& Zolghadr, A. (2013). Topology Optimization of Trusses Considering Static and Dynamic Constraints Using The CSS (Vol. 13).

Kennedy, J., \& Eberhart, R. (1995, 27 Nov.-1 Dec. 1995). Particle Swarm Optimization. Paper presented at the Proceedings of ICNN'95 - International Conference on Neural Networks.

Savsani, V. J., Tejani, G. G., \& Patel, V. K. (2016). Truss Topology Optimization with Static and Dynamic Constraints Using Modified Subpopulation Teaching-Learning-Based Optimization. Engineering Optimization, 48(11), 1990-2006. doi: 10.1080/0305215X.2016.1150468

Storn, R., \& Price, K. (1997). Differential Evolution - A Simple and Efficient Heuristic for Global Optimization over Continuous Spaces (Vol. 11).

Tejani, G., Savsani, V., Bureerat, S., \& Patel, V. (2017). Topology and Size Optimization of Trusses with Static and Dynamic Bounds by Modified Symbiotic Organisms Search (Vol. 32).

Venkata Rao, R., Savsani, V., \& P. Vakharia, D. (2011). Teaching-Learning-Based Optimization: a Novel Method for Constrained Mechanical Design Optimization Problems (Vol. 43).

Xu, B., Jiang, J., Tong, W., \& Wu, K. (2003). Topology Group Concept for Truss Topology Optimization with Frequency Constraints. Journal of Sound and Vibration, 261(5), 911925. doi: https://doi.org/10.1016/S0022-460X(02)01021-0

Yang, X.-S. (2011). Review f Meta-Heuristics and Generalised Evolutionary Walk Algorithm (Vol. 3). 